\title{
CESIS
}

Electronic Working Paper Series

Paper No.76

\section{Regional Development and Knowledge}

\author{
By Charlie Karlsson and Börje Johansson
}

This paper reports on work in the project "The Competitiveness of firms, regions and industries in the knowledge-based economy. What room for job-rich growth in Europe", financed by the Sixth Framework Programme of the European Union. The paper does not reflect the official view of the European Commission". 


\title{
Regional Development and Knowledge
}

\begin{abstract}
This paper focuses on the concept of knowledge and examines models depicting and explaining the role of knowledge in regional development and provides an assessment of empirical studies of how knowledge affects growth and development in functional regions. For this paper it is crucial to understand those factors that make knowledge spatially sticky and knowledge-production capacity trapped. It is equally important to explain the conditions for knowledge flows and diffusion. The presentation also widens the view by extending the analysis of knowledge creation to include aspects of creativity. Since location advantages and especially the knowledge-based advantages have the feature of moving in slowly path-dependent processes the regional policy needs to focus on structural adjustments of tangible and non-tangible infrastructure to succeed.
\end{abstract}

JEL classifications: D 80, R 11, R 12

Key words: knowledge, functional regions, regional growth, knowledge creativity, localization and spatiality processes. 


\section{INTRODUCTION}

This chapter examines models depicting and explaining the role of knowledge in regional development and provides an assessment of empirical studies of how knowledge affects growth and development in functional regions. In this endeavour, it is crucial to understand those factors that make knowledge spatially sticky and knowledge-production capacity trapped. It is equally important to explain the conditions for knowledge flows and diffusion. The presentation also widens the view by extending the analysis of knowledge creation to include aspects of creativity.

\subsection{Region and Regional Development}

In recent decades, the world has witnessed the emergence of a global knowledge economy, in which regions increasingly are being looked upon as independent, dynamic market places, which are connected with other regions via knowledge and commodity flows. Each such region has its own base of scientific, technological, and entrepreneurial knowledge, represented by knowledge assets of firms and other organisations located in the region, and the human and social capital associated with the region's population. A region is also characterised by its education system, its ongoing knowledge-production activities in universities, research laboratories and firms, as well as its import and export of knowledge.

The above picture provides a meaningful description only when we have a clear concept of what a region is. We shall use the concept functional (urban) region as a place for knowledge creation, appropriation, and absorption, as well as a place for transforming knowledge to innovations (Jaffe, Trajtenberg \& Henderson, 1993; Glaeser, 1999). This choice may be based on the idea that a region is an arena for exploiting communication externalities (Fujita \& Thisse, 2002), which requires that the actors in the region can exercise frequent face-to-face interaction. Another associated aspect is the concept labour market region, in which knowledge spreads as individuals change their job affiliation (Zucker, Darby \& Armstrong, 1998). Extending this thought brings us to the concept regional innovation system as a criterion for identifying the borders of a region (Andersson \& Karlsson, 2006). 
Often it is argued that processes of innovation are prerequisites for sustainable growth of regions as well as nations. In the subsequent presentation, regional economic growth is treated as a central aspect of regional development. Additional aspects of regional development are population growth, increase of land values and wealth of the population.

\subsection{Localised Knowledge}

Although we have not yet provided any categorisation of knowledge, we may ask a preliminary question: which types of knowledge tend to be clustered spatially? Knowledge in the form firm assets, such as patents, employed technology and R\&D capacity will be concentrated in space to the extent that knowledge-rich firms are colocated in the same region. Knowledge in the form of human capital becomes localised as the result of a clustering process, where concentration of persons embodying knowledge and creativity attracts knowledge-intensive person to migrate to such placers and to remain there.

Localised knowledge will have a sustainable influence on a region's future development if the knowledge resources of the region change on a slow time scale. When this applies, a region with small knowledge resources can accumulate more knowledge only over an extended time-period, whereas a knowledge-rich region will tend to remain such far into the future.

History certainly offers some examples where household migration and firm relocation has been fast, but slow adjustments are observed much more frequently, and large urban regions have often a history that can be measured in centuries. How can we explain this temporal phenomenon? In the subsequent presentation, we will refer to two basic factors. The first comprises the infrastructure and the amenities that operate as attractors for both firms and households, and which constitute slowly changing location attributes (Johansson \& Karlsson, 1992). The second factor refers to a fundamental externality in the so-called NEG-theory (new Economic Geography). Paraphrasing Krugman (1991), the externality can be formulated in the following way: 
(ii) Knowledge-intensive labour is attracted to places where knowledge-dependent firms are located.

(ii) Firms with knowledge-dependent activities are attracted to places where knowledge-intensive labour is located.

The described externality can generate cumulative growth, while at the same time making the co-location of a knowledge-rich labour force and knowledge-demanding industries resilient to change. The pertinent firms remain in the region because of its favourable accessibility to knowledge resources, and the labour force has a corresponding advantage of remaining in a place with favourable accessibility to knowledge-handling job opportunities.

\section{THE NATURE OF KNOWLEDGE IN THE ECONOMY}

The concept of knowledge is elusive and interpretations easily become deceitful. To make the concept useful for our analysis we will discuss the form of knowledge and examine the different ways that it can affect the economy. In addition, we ask: from where does knowledge come and why is it sticky?

\subsection{The Form of Knowledge}

Frequently, we can find that the terms knowledge and information are used interchangeably, and this has worried some authors (e.g. Kobayashi, 1995). From one point of view, information is simply a carrier of messages, and such messages can contain statements about knowledge. It is perhaps in this context that the distinction between information and knowledge is most vital, because some forms of knowledge are difficult (or impossible) to codify and thus to transform into useful messages.

Focusing on knowledge that can be related to production activities of firms and other organisations (like public authorities etc.), we recognise the following three categories: 
- Know-how, which is always embodied in persons or embedded in an organisation

- Know-why, which has the nature of systematic and publicly accepted (scientific) explanations, which can be stored in codified form, but may require skill to decode.

- Knowledge in the form of human capital, which represents both know-how, and know-why that is embodied in individuals.

In our analysis it is vital to make the distinction between know-why and know-how, where know-why refers to a capacity to explain and understand, whereas know-how signifies expertise, skills and practical attainments. An entrepreneur or a salesperson may be skilful in finding customers and make them buy the products offered for sales, while at the same time being unaware of why the marketing methods are successful. To answer the latter question, know-why has to be consulted.

Know-why relates to science in the sense that it does not exist - by definition - if it has not been codified. In contradistinction, the presence of know-how is not constrained by the possibility to formulate codified instructions. Know-how is based on experience and training and often so difficult (or uneconomical) to codify that it becomes tacit.

From another perspective, Karlsson \& Johansson (2006) introduce the following three knowledge concepts:

(1) Scientific knowledge in the form of basic scientific principles that can form a basis for the development of technological and entrepreneurial knowledge.

(2) Technological knowledge - implicit and explicit blueprints - in the form of inventions (or technical solutions) that either materialise in new products or are readily used in the production of goods and services.

(3) Entrepreneurial knowledge that comprises business-relevant knowledge about products, business concepts, markets, customers, and so on. 
In this context, it seems important to remark that a scientist performs $R \& D$ activities, while making use of know-how about effective and feasible ways to conduct research. Attempts to codify such know-how are often quite primitive and superficial.

In concordance with Schumpeter's analysis, scientific knowledge functions as a background to or platform for technological and entrepreneurial knowledge in the innovation process (Schumpeter, 1934). As suggested by Nelson \& Winter (1982), a firm’s innovation can be a change in the routines (technique, organisation etc.) of the firm and/or a new product (e.g. a change in attributes of a good or a service). In both these cases, an innovation is the combined result of technological and entrepreneurial knowledge.

In dealing with the different concepts of knowledge it is essential to characterise them according to the degree to which they are rivalrous and excludable (cf., Cornes \& Sandler, 1986). A purely rival good has the property that its use by one firm or person precludes its use by another, whereas a purely non-rival good has the property that its use by one agent in no way limits its use by another. Excludability relates to both technology and legal systems (Kobayashi \& Andersson, 1994). A good is excludable if the owner can prevent others from using it. While conventional goods are both rival and excludable, pure public goods are both non-rival and non-excludable. As stressed by Arrow (1962) this creates a conflict, since a firm will only be motivated to carry out R\&D if competitors can be excluded, whereas society will benefit if the knowledge (innovation) is allowed to diffuse to many firms. In a multiregional context, one can identify a similar conflict between stimulating intraregional and preventing interregional knowledge spillovers.

\subsection{How Does the Knowledge Affect the Economy?}

What type of knowledge can be identified for a firm? The following three components comprise a firm's primary types of knowledge:

- Knowledge about firm routines

- Knowledge about product varieties

- Knowledge as a capacity to carry out R\&D 
Firm routines include techniques and approaches that are applied in production, administration, logistic, distribution, and transaction activities. In this way, the routines (traditionally called production technique) are a manifestation of the firm's knowhow, where the latter also includes the firm's capability to combine product attributes of its output varieties. For an innovative firm, routines may also comprise its procedures to improve - gradually or stepwise - its routines and to develop its product varieties.

The above considerations are illustrated in Figure 2.1, which emphasises that the know-how about how to develop routines is a combination of the firm's experiences, the inflow of knowledge from outside the firm, and the firm's know-why. The most important observation is that the interaction between firms in a region can be a major generator of the region's compound knowledge. Given the structure outlined in the figure, how do economic models describe the influence of knowledge? When answering this, we identify two approaches in orthodox theory:

- Knowledge affects (augments) the production function of a firm, which implies that it improves the productivity of inputs (Chambers, 1988).

- Knowledge affects the value ladder of product varieties produced by the firm (Grossman \& Helpman, 1991).

In microeconomic models, knowledge often is represented by a factor that influences a firm's production function. The latter describes how a firm transforms (i) current inputs, (ii) labour, and (iii) physical, human and organisational capital to outputs. In its most naked form, the production function describes how labour and capital can be used to obtain output. In this case, knowledge is a factor that shifts the productivity of labour and capital upwards. 


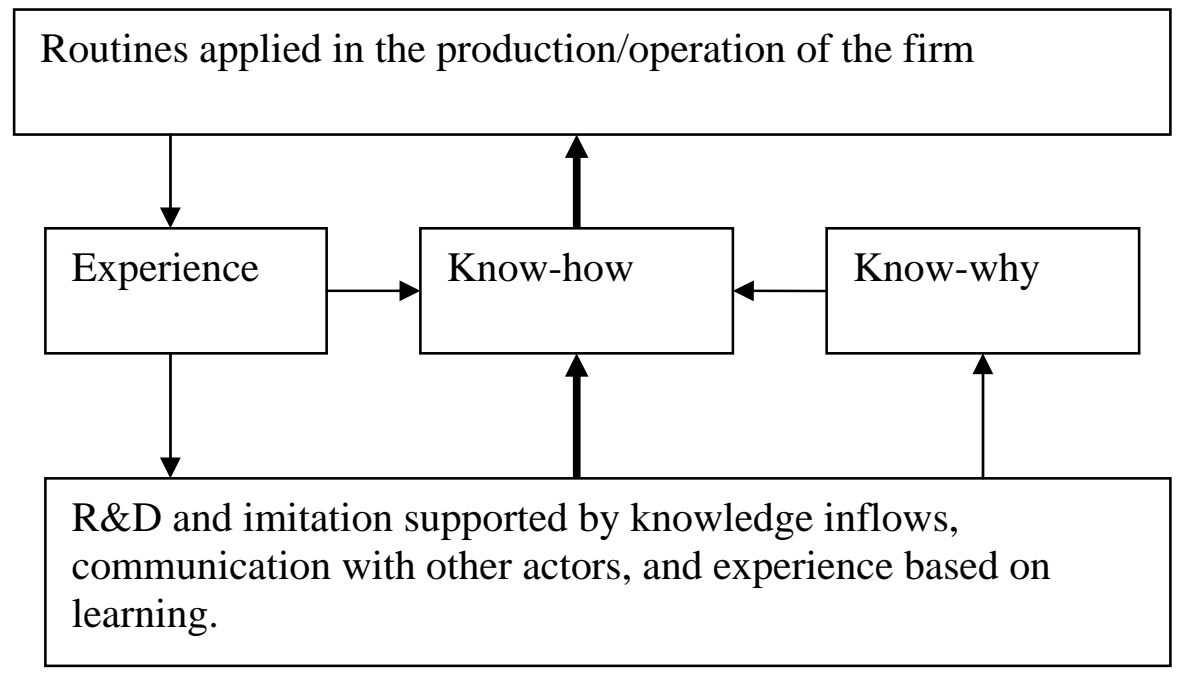

Figure 2.1: Knowledge development of a firm

The microeconomic production function isolates the study of knowledge to a question of the existing routines of established and potential firms. However, it excludes an important temporal phenomenon by not considering the routines a firm has available when improving its production process. When such issues are at the forefront, researchers take the step into evolutionary economics. Attempts to study product development takes the analyses even further into the territory of industrial dynamics and evolutionary processes (Nelson \& Winter, 1982; Dosi, et al., 1988)

How can we take the step from the picture in Figure 2.1 to a model description of how knowledge affects the economy of a region? Obviously, such a step requires heroic efforts. Following a mainstream approach leads to a regional production-function model of the following kind:

$$
\begin{aligned}
& Y=F(K, L, N) A \\
& A=\int_{t} \dot{A} d t \\
& \dot{A}=G(\hat{K}, \hat{L}, \hat{N}) A
\end{aligned}
$$

where $K, L$ and $N$ represent capital, labour and human capital employed in the production of an aggregate output, while $\hat{K}, \hat{L}$ and $\hat{N}$ represent capital, labour and human capital employed in the production of knowledge (know-how) as signified by $A$, where $\dot{A}=d A / d t$ signifies the change of $A$ per time unit. The three equations also 
need to be supplemented by a specification of the temporal motion of $K, L$ and $N$ as

wells as of $\hat{K}, \hat{L}$, and $\hat{N}$. When equation (2.1c) is excluded and (2.1b) is exogenously given, we have an aggregate regional production model of Solow type (Solow, 1994). Otherwise, the equation system represents a regional endogenous-growth model (Romer, 1994). In either case, the model outlined in (2.1) tries to capture knowledge interaction and creation of all actors in a region into equations (2.1b) and (2.1c). In particular, it disregards all knowledge flows to and from the region. Moreover, if one specifies the equation system for individual sectors of a regional economy, one has to consider knowledge flows between sectors (Romer, 1986).

\subsection{Sources of Knowledge Flows and Knowledge Creation}

Innovation processes generate new products and new routines of innovating firms and other organisations (Nelson \& Winter, 1982). The knowledge employed and applied in innovation activities has in each individual case several sources. For firms in a functional region, we can identify the following three principal sources of knowledge:

- Knowledge that originates from knowledge creation, based on R\&D efforts in firms, research laboratories and universities - partly carried out as interactive processes in regional innovation systems.

- Knowledge flows between actors inside a region, due to unintended local diffusion, knowledge interaction, movement of employees when individuals change employer, and when firms employ individuals who leave education and research organisations.

- Knowledge flows from sources outside the region based on various forms of long-distance interaction, foreign direct investments (FDIs) and flows inside each company group’s internal networks, in particular inside multinational firms.

The literature offers a steady progression of methods and frameworks to examine both intra-regional and inter-regional knowledge flows. These approaches examine the importance of knowledge flows for a firm's patenting, R\&D efforts, innovation output in the form of novel products and similar measures. In these studies, the knowledge production function has remained a workhorse, relating a firm's knowledge inputs to its 
output of patent applications (Varga, 1997; Zucker, Derby \& Brewer, 1998). These studies have shown that some innovative firms are highly dependent on knowledge generated by local university R\&D (Feldman \& Audretsch, 1999). The knowledge transfer and exchange may rely on a whole spectrum of mechanisms, such as (i) a flow of newly trained graduates from universities to industry, (ii) technological spillovers of newly created knowledge from universities to industry, (iii) industrial purchases intellectual property of universities, (iv) university researchers working as R\&D consultants or serving on company boards, (v) university researchers leaving universities to work for industry, and (vi) university researcher starting new firms. In addition, universities may create incubators, enterprise centres and science parks to improve interaction with industry and to facilitate knowledge exchange between industry and university.

Some scholars have used the knowledge production function to discriminate between localised knowledge flows from knowledge exchange in long-distance networks (Varga, 2002; Andersson \& Ejermo, 2005). At the same time, many empirical analyses emphasise that the relevant sources are local, based on $R \& D$ that takes place in the same region as the firm that makes use of the $R \& D$ results.

Recent studies have also compared a firm's accessibility to R\&D activities in universities and in other firms, where accessibility here refers to the possibility to get in touch with R\&D activities, as well as the costs of the associated contacts. A clear outcome is that accessibility to other firms’ $R \& D$ resources has a much stronger impact on the knowledge production than the accessibility to $\mathrm{R} \& \mathrm{D}$ resources in universities (Andersson \& Ejermo, 2005; Gråsjö, 2006). Also in this case, the accessibility measures imply that local knowledge flows are persistently important, whereas long-distance flows have very small impacts - except in one case. For firms that belong to a company group, one can establish that these firms can utilise the internal networks of its group to overcome long distances. These company groups are consistently multinational firms. Obviously, a multinational firm can locate subsidiaries in the proximity of places with specialised excellence, from which novelties can be developed and transferred through the internal networks of the multinational organisation (Dunning \& Narula, 1995). 
Evidently, the R\&D efforts by an individual firm are a main factor in its knowledge production. However, the $R \& D$ resources and $R \& D$ efforts of a firm have a second motivation. Firms with a large and active R\&D staff have also a large absorptive capacity with regard to external knowledge flows. Pfaffermayr \& Bellak (2002) argue that this gives them an advantage in both knowledge absorption and creation. Recalling that we have concluded that knowledge flows are local in nature, it seems natural to conjecture that regions may improve their absorptive capacity as a consequence of hosting firms with such capacities.

\subsection{Why is Knowledge Spatially Sticky?}

In Arrow's (1962) contribution, it is observed that obstacles to communication may imply that technological as well as scientific knowledge may lose the property of being a pure public goods. In fact, the most realistic assumption is that knowledge flows are affected by friction that may vary in strength for various components of knowledge. Thus, there are friction costs for someone trying to transmit or sell knowledge assets, and such costs also burden someone who tries to buy knowledge or to acquire it in other ways.

In every particular case of knowledge transmission or transfer, the friction cost will vary because of geographic and other communication distances. Friction appears when knowledge is complex as argued by Beckmann (1994, 2000), and when it is tacit as described by Polanyi (1966). As a consequence, knowledge will be sticky in the words of von Hippel (1994). Face-to-face interaction is an essential requirement for knowledge exchange, because the complex and tacit knowledge can be communicated between agents only when they have the opportunity to calibrate their coding, encoding and interpretation capabilities.

The cost of transmitting knowledge increases together with the distance. Since the transmission of complex and tacit knowledge requires face-to-face contacts, knowledge exchange requires an extensive amount of somewhat diffused movements throughout various transportation networks. ${ }^{1}$ Knowledge exchange is an essentially

\footnotetext{
${ }^{1}$ Historically, the transfer/communication of rich information has required proximity and specialised channels to customers, suppliers, and distributors. However, we must acknowledge the possibility that the new developments are undermining the traditional chains and business models, and that new
} 
interpersonal activity that is defined here as any action that can contribute to the process of the disclosure, dissemination, transmission, and communication of knowledge. This suggests that knowledge is neither shared ubiquitously nor passed around at zero cost (Teece, 1981).

The above implies that knowledge exchange and transmission can be made at lower costs when the transmission distance is short. Therefore, knowledge has the feature of being spatially sticky, and some regions can have more knowledge assets than other regions. It is important to observe that knowledge exchangers may build knowledge networks by investing in "channels" or links for knowledge exchange (Beckmann, 1994). Such networks will reduce the importance of distance, but the investment costs will be recovered only to the extent that the knowledge links are used frequently. Evidently, we can partly explain the existence of multinational companies with their spatially distributed firm units by such network advantages (Kummerle, 1999; Narula, 2002). Antonelli, Marchionatti \& Usai (2003) argue that stickiness of knowledge implies that knowledge can be shared by firms in a local environment of a functional region with little risk that the knowledge diffuses outside the region.

Let us finally observe that knowledge is an input to R\&D activities and that the latter are carried out by firms, universities, laboratories and consultants that interact in innovation efforts. The above observations then imply that R\&D activities will also be spatially sticky. In particular, it becomes relevant to describe and measure a firm's accessibility (potential of opportunities for interaction) to knowledge sources and to R\&D activities of other actors. Studies by Andersson \& Ejermo (2004 \& 2005) and, in particular, Gråsjö (2006) show that the knowledge creation and innovation activities of a firm located in a municipality, $m$, is influenced by two accessibility factors. The first is the local accessibility to knowledge sources inside the municipality, $A_{m}^{L}$, and the second is the regional accessibility to knowledge sources inside the functional region to which the municipality $m$ belongs, $A_{m}^{R}$. On the other hand, the external accessibility to knowledge sources outside the region $R$ has frequently insignificant influence.

structures - generally less dependent on physical communication channels - might become more and more often an economically viable option (cf. Teece, 1998). 
The two accessibility measures applied in Gråsjö (2006) have the following form:

$$
\begin{aligned}
& A_{m}^{L}=G_{m} \exp \left\{-\lambda^{L} t_{m m}\right\} \\
& A_{m}^{R}=\sum_{s \in \hat{R}} G_{s} \exp \left\{-\lambda^{R} t_{m s}\right\}
\end{aligned}
$$

where $G_{s}$ refers to knowledge resources in municipality $s, t_{m m}$ is the average time distance between zones in municipality $m, t_{m s}$ is the time distance between municipality $m$ and $s, \hat{R}$ is the set of municipalities in the region to which $m$ belongs -except municipality $m$ itself. Moreover, $\lambda^{L}$ is the distance discount factor inside a municipality and $\lambda^{R}$ is intraregional distance discount factor. The finding in Gråsjö is, that $A_{m}^{L}$ and $A_{m}^{R}$ influence the knowledge creation in $m$ as two independent factors. Results from Johansson, Klaesson, \& Olsson (2002) show that $\lambda^{R}>\lambda^{L}$, emphasising the importance of proximity for knowledge interaction.

\section{KNOWLEDGE IN THE REGIONAL MACRO ECONOMY}

In this chapter, the main objective is to formulate our understanding of how knowledge affects economic growth and development in a region. Can we claim that one region develops faster because of its superior knowledge assets? What is the role of human capital and accumulated R\&D results? To what extent can a functional region be analysed as a separate entity, and which types of interregional influences must be taken into consideration?

\subsection{The Regional Production Function and Endogenous Growth}

A natural starting point for gaining an increased theoretical understanding of the emerging knowledge economy is the new endogenous growth theory, which emphasises the role of the stock of accumulated knowledge and the growth of this stock. En- 
dogenous growth models depict the growth process of an isolated economy and suggest that continuous increases in technological knowledge influence the aggregate economic growth, and they should perhaps be addressed as R\&D models of economic growth (Romer, 1990).

The basic idea, as described in (2.1), is that one part of an economy's resources $(K, L$, $N$ ) are used to produce an output that can be used for consumption as well as investment, while another part of the economy's resources $(\hat{K}, \hat{L}, \hat{N})$ is employed in the production of new technology. In such a single-region R\&D model, the separation from the rest of the world becomes questionable. The basic reason for this is that regions are specialised and that they trade with each other and because of this, technologies will diffuse from region to region.

In its most simplified form, an R\&D growth model has fixed savings behaviour such that $K$ and $\hat{K}$ change in a fixed proportion to the level of output $Y$. The merit of the model is that technological development, represented by the change $\dot{A}=G(\hat{K}, \hat{L}, \hat{N}) A$ is determined by the allocation of the three resources $(\hat{K}, \hat{L}, \hat{N})$ to knowledge creation. The conventional formulation has been criticised by Solow (1994) for the constant proportionate increase in output that a growing A can generate, as given by $Y=F(K, L, N) A$. Together with the knowledge production, $\dot{A}=G(\hat{K}, \hat{L}, \hat{N}) A$, an economy can expand without limits. Ultimately, this is not a valid criticism of the basic idea behind endogenous growth, but a discussion of the functional form (i) the knowledge accumulation dynamics, and (ii) the effects that new knowledge has on the regional economy. Obviously, some new knowledge will make parts of the "old knowledge" obsolete.

From the perspective of a functional region, there is another problem with the formulation of the endogenous growth model. In a functional region, the change in the productivity variable, $A$, depends on various types of “technology flows" from other regions. To a large extent new production technology is embodied in imports of new production equipment, and imports of new product forms a basis for imitation-like responses that will also change the A-variable. Even if the local knowledge produc- 
tion gets its strongest stimuli from knowledge resources in the regional milieu, knowledge flows from other regions should be expected to have a great influence on the development of individual regions.

The R\&D model due to Romer may be compared with Lucas' growth model with endogenous human capital accumulation, depicting how the gradual embodiment of knowledge in human beings (Lucas, 1988) is a driving force behind economic growth. Just like the contribution by Romer, Lucas recognises that economic growth is not emerging automatically as 'manna from heaven', but is the result of deliberate actions and choices of various stakeholders, including the government (Nijkamp, 2003).

In terms of the formal description in (2.1), the Lucas model is a human capital model, which extends the Solow model by employing the following two equations to describe capital accumulation:

$$
\begin{aligned}
& \dot{K}=d K / d t=s_{K} Y \\
& \dot{N}=d N / d t=s_{N} Y
\end{aligned}
$$

where $s_{K}$ and $s_{N}$ denote the investment in physical and human as a proportion of aggregate output, $Y$. This model does not generate the same never-ending growth in output per capita, as does the Romer model. Lucas' formulation is founded on straightforward principles. Economic agents decide according to their preferences about the allocation of their non-leisure time between current production and the accumulation of human capital, and thereby they determine the growth rate of output. The model assumes that the larger a region's accumulated human capital, the more productive every inhabitant of the region will be. By treating the regional population as a trapped resource, the model is readily applicable for analysing individual (separated) regions. However, the interregional implication is that wage differentials between regions will develop and generate incentives to migrate from regions with lower to regions with higher wage levels. 
In Romer (1990), technological progress is the result of profit-motivated investments in production of technological knowledge by private economic agents. These economic agents are acting in an economic environment characterised by monopolistic competition along the lines suggested by Dixit \& Stiglitz (1977), which explicitly considers the trade-off between the output of goods and their variety. Markets are assumed to be imperfectly rather than perfectly competitive, because investments in R\&D are feasible only if price exceeds production cost by some margin. Another distinguishing feature is the existence of increasing returns, since technological knowledge is treated as a non-rival, partially excludable good. Firms are able to maintain ownership of at least a portion of the value of the increased productivity or better product performance won through their R\&D (Nelson, 1997). In such a framework, each firm that develops new technological knowledge gains some market power and thus can earn some monopoly profits on its investments.

\subsection{Does Knowledge make a Difference?}

The growth models based on accumulation of human capital and R\&D results were formulated in response to the observation that the classical growth model of Solow type could not help to explain that the GDP per capita varies considerably between different countries and between different regions.

Firstly, the new versions of growth models are compatible with the famous statements about economic growth by Kaldor (1963): (i) per capita output continues to grow over time, (ii) physical capital per worker grows over time, (iii) the rate of return to capital is nearly constant, (iv) the capital to output ratio remains approximately constant, (v) the proportion between labour and physical capital income remains approximately unchanged over time, and (vi) the growth rate differs substantially between countries (as between regions).

As observed in Griliches (1995) and in Barro \& Sala-i-Martin (1995) the empirical research on the relation between $\mathrm{R} \& \mathrm{D}$ and economic growth is still embryonic. Griliches discusses three levels of identification: the firm, the industry and the national level. In all three cases cross-section studies yield the result that accumulated $R \& D$ is positively related. This observation amounts to saying that firms, industries, 
regions, and countries with high productivity levels also have a large "stock" of cumulated R\&D.

Time series analyses can focus on how accumulated R\&D affects the output growth of firms and regions - as well as the productivity growth. Such analyses may also examine how R\&D investments influence growth rates. For these types of questions, the empirical findings are more unclear and ambiguous. Especially studies of the development of firms show uncertain results and there is a general $R \& D$ endogeneity problem, which means that there is a causality problem when comparing $R \& R$ levels and productivity levels (Griliches, 1995).

Historically, growth accounting offers an approach to investigate empirically how growth rates depend on productivity enhancing factors such as efficient resource allocation, scale factors (extent of market) and technology (Dension, 1962 \& 1967). Although this approach is not based on a theoretical model, it provides an alternative for examining regional growth rates in a similar way as has been done frequently for countries. Studies like Cheshire \& Gordon (1998), and Cheshire \& Magrini (2002) provide examples that point in this direction. The suggestion to use a growth accounting framework for systematic empirical analyses does not preclude ambitions to develop theoretically consistent models of regional growth.

\subsection{Interregional Knowledge Flows and Multiregional Growth}

Large regions have a large internal market, which means that firms sell a large share of their output to customers inside the region, and firms' purchases of inputs display a similar proximity bias. For small regions, the local marker is small and external transactions become more important. More generally, flows of goods, services, and knowledge vary with the size of a region and the geography of neighbouring regions.

It is possible to construct an empirically tractable geography based on the concept functional (urban) region, where such a region is characterised by having time distances that are shorter than 60 minutes between arbitrary pairs of locations in the region. With such delineation, a functional region qualifies as an arena for frequent face-to-face contacts, an arena that permits knowledge diffusion and exchange with 
small friction. In this way, the economic geography is a two-layer formation, with a network for interaction inside each region and a second network for interaction between different regions.

In order to illuminate different aspects of interregional knowledge diffusion we shall make use of a model introduced in Andersson \& Mantsinen (1980) and Andersson (1981). The core of the model is a production function for each region $r$, $Q_{r}=Q\left(K_{r}, A_{r}\right)$, where $K_{r}$ represents the production capital and $A_{r}$ the accessible knowledge in the region. The knowledge resources in any region $\mathrm{r}$ is given by $G_{r}$, but the region can also benefit from knowledge $G_{s}$ in other regions, denoted by $s$. The variable $A_{r}$ summarises the compound effect of knowledge inside and outside the region.

The model components introduced above are sufficient to depict a landscape of interregional knowledge influences in a stylised model where the $G$-variable may comprise scientific, technological, and entrepreneurial knowledge resources as well as the capacity to develop new knowledge. Assume that this complex body of resources can be treated as a spatial public good, such that $G_{s}$ in region $s$ influences the accessible knowledge in region $r$ via distance-decay factor, $f_{s r}$, which yields the following expression for the total accessible knowledge in region $r$ :

$$
A_{r}=\sum_{s} f_{s r} G_{s}
$$

where $f_{r r}>f_{s r}>0$, for $s \neq r$. In this model, the accessible knowledge will change when any of the $G$-variables change, and such changes can be described as the outcome of R\&D processes, depicted by the following differential equation:

$$
\dot{G}_{r}=H\left(g_{r} \tau_{r} Q_{r}\right)
$$

where $d H / d z>0$, where $\tau_{r}$ signifies the share of output, $Q_{r}$, that is allocated to knowledge-creation activities, and where $g_{r}$ is the productivity of R\&D in region $r$. A model of the multiregional development obtains, if we introduce a second dynamic 
equation that describes the accumulation of production capital, $K_{r}$, in the following way:

$$
\dot{K}_{r}=s_{r}\left(1-\tau_{r}\right) Q_{r}
$$

where $s_{r}$ signifies the investment coefficient of region $r$. According to Andersson \& Mantsinen (1980) that with a suitable specification of the model parameters, there will exist a long-run growth equilibrium, towards which the solution may approach over time in a process with regional divergence phases followed by convergence.

At any specific point in time the output level of region $r$ is determined by $Q_{r}=Q\left(K_{r}, A_{r}\right)$. Following suggestions in Weibull (1976), the distance-decay factor is specified as $f_{s r}=\exp \left\{-\lambda t_{r s}\right\}$. This yields the following expression for accessible knowledge in region $r$ :

$$
A_{r}=\sum_{s} \exp \left\{-\lambda t_{s r}\right\} G_{s}
$$

Where $t_{r s}$ is the time distance between $\mathrm{r}$ and $\mathrm{s}$, and where $\lambda$ is a time-sensitivity parameter that may be different for intraregional and interregional knowledge exchange (Johansson, Klaesson \& Olsson, 2002). As long as $0<t_{r r}<t_{s r}$ for $s \neq r$, region $r$ 's own knowledge, $G_{r}$, is less discounted than any other region's knowledge resource, $G_{s}$. For a small region however, we may have that $G_{s}$ is much larger than $G_{r}$, and then the latter factor may contribute much more to region $r$ 's accessible knowledge.

The conditions for knowledge diffusion (or spillover) are such that shortened time distances in any part of the geography will improve the balanced growth rate across regions. The same applies in the model when $\lambda$ is reduced because of improved regional innovation systems. These conclusions indicate the importance of considering the interregional knowledge flows in the analysis of knowledge as a "driving force" in regional development. 


\section{KNOWLEDGE CREATION IN A REGION}

For several decades social scientists have pointed out that, the contemporary developed economies have gone through fundamental changes. Different authors have used different concepts to characterise what they have seen as the most basic aspect of these changes. To indicate this, they have introduced concepts such as the information society, the service society, the post-industrial society, and the knowledge society. We will refer to this as the C-society (Andersson, 1985a) when discussing the creative region and regional innovation systems

\subsection{R\&D Activities and Creativity}

A classical statement by Schumpeter is that an innovation is the result of "novelty by combination”. Such combinations have to be fuelled by creative individuals and groups of individuals. In the contributions made by Florida (2002, 2005a \& b) this aspect is emphasised by recognising the critical role of talented individuals, which implies that the concentration of innovations will be influenced by the location preferences of such individuals, belonging to "the creative class".

In a Nordic context, the focus on creativity was introduced in the 1980's is a series of books by Andersson (1985 a \& 1988) and Andersson \& Strömquist (1989). Two ideas in these contributions are essential in the analyses of this chapter. First, it is suggested that the knowledge endowment of a region has the nature of non-material infrastructure. Second, the theory formulation is founded on a model of individual creativity, emphasising seven abilities of the human brain. These are: (i) the heuristic ability, and the ability (ii) to remember, (iii) to detect deep structures, (iv) to see and use ambiguity, multiplicity and variety, (v) to appreciate paradoxes and surprises, (vi) to use disequilibria, and (vii) to use fundamental uncertainty.

Andersson (1985a \& 1986) makes a distinction between individual and social motivation for creativity efforts. If internal reinforcement mechanisms have a greater importance for explaining the total creativity level of individuals than simple reward or coercion arguments, it is difficult to stimulate the creative output of individuals with the 
help of short-term policy measures. Instead, such policies will have to identify slow measures of building a regional creativity-enhancing infrastructure.

The major suggestion in Andersson (1985 a \& b), as well as in Castells (1989), Hall and Preston (1988), Hall (1990), Noyelle \& Stanback (1985), is that recent decades of the $20^{\text {th }}$ century represent a clear path away from the industrial society, characterised by goods-handling activities to a C-society, characterised by knowledge-handling and development activities. In this transformation, the major driving force is creative activities, which generate new knowledge spurred by culture and communication. Development, handling and presentation of new knowledge and information employs a steadily increasing share of the labour force and have strong spillover effects on industrial activities in manufacturing as well as in service production.

With the emergence of the C-society, the resource base in developed economies is no longer natural resources, energy, etc., but education and assets based on creative activities. At the same time, the composition of infrastructure is changing. Traditional means of transportation are complemented, and partly substituted by the communication networks created by modern information technology. Among the traditional means of transportation, road and air transport gradually get a more dominating role. Access to material and immaterial networks is becoming more and more critical.

In this change process, industrial regions will lose their previous advantages and may have to restructure to regain prosperity. Instead, regions that afford creative milieux will benefit (Aydalot \& Keeble, 1988). Moreover, urban regions with rich import networks and diversified import activities have a favourable position, because they acquire novelties from the world economy earlier than other regions. Irrespectively of how strong a region is in terms of $R \& D$, it only produces a tiny share of all new knowledge in the world. Imported novelties and ideas can generate new economic activities in import nodes, given that they host a sufficient amount of knowledge resources. 
Andersson (1985 a) summarises the characteristics of creative milieus. ${ }^{2}$ Many different factors work together in a creative milieu. The creative process can be seen as a form of dynamic synergy. To initiate a creative process many factors must be able to influence each other in an interdependent process of interaction. This type of process puts great demands on the regional milieu. It appears that the regional milieu must be of large scale but still culturally versatile, rich of deep original knowledge and competence and characterised by good communication possibilities internally and externally.

For the intraregional communication, physical nearness seems to be of great importance. To achieve considerable synergy effects there is a need for diversity and variation. The different activities in a creative region are often of small scale as individual activities. Industries do grow not by quantitative growth of the existing activities but through the emergence of new activities. The following seven factors seem to be fundamental conditions for creative processes:

1. Benevolent or tolerant attitudes towards experiments.

2. Versatile composition of knowledge and competences.

3. Versatile and relatively unregulated financial basis for science, entrepreneurship and cultural life.

4. Good possibilities for spontaneous and informal personal contacts between different parts of the region and with other regions.

5. Many-sidedness rather than functional division of the social and physical milieu.

6. A feeling that the needs are larger than actual resources or possibilities.

7. A flexible social and economic organization, which sometimes goes beyond the borders to structural instability.

The characterisation of the creative region in the contemporary C-society will be further elaborated in the subsequent subsection. We may also observe that ideas of the Csociety suggest that large, knowledge-rich urban regions will have a clear economic

\footnotetext{
2 The concept of creative milieu can be compared with the concept of "milieu of innovation" introduced by Castells (1989, p. 82). "By a milieu of innovation we understand a specific set of relationships of production ... based on a social organisation that by and large shares a work culture and instrumental goals aimed at generating new knowledge, new processes and new products.”
} 
advantage in comparison with smaller regions. In subsection 4.3 we discuss the opportunities of smaller regions.

\subsection{Characteristics of the Creative Region}

What are the characteristics of the creative region in the contemporary C-society, i.e. what are the environmental conditions at the regional level that stimulate creative activities? Creative activities are in particular stimulated in regions, which can offer the necessary level of competence and diversity required for generating potentially synergetic situations (Andersson, 1985c). Such conditions are in most cases available in large urban, i.e. metropolitan, regions.

The fundamental role of metropolitan regions in the creative process depends upon their role as communication centres. Metropolitan regions are centres of international communication in culture, business, politics, and science. They also offer good opportunities to develop closely-knit intra-regional communication networks within as well as between sectors of society. One important reason why creative activities are concentrated in metropolitan regions is that these regions offer a physical proximity which facilitates the integration of multidisciplinary knowledge that is tacit and therefore "person-embodied" rather than "information-embodied" as well as the rapid decision-making needed to cope with uncertainty (cf., Patel \& Pavitt, 1991).

Andersson (1985c) concludes that creativity as a social phenomenon primarily develops in regions characterised by:

1. High levels of competence.

2. Many fields of academic and cultural activity.

3. Excellent possibilities for internal and external communications.

4. Widely shared perceptions of unsatisfied needs.

5. A general situation of structural instability facilitating a synergetic development.

In the literature, creative regions are also characterised as learning regions (cf. Morgan,1997). The current focus on learning regions reflects the increasing recognition of 
the role of knowledge and learning as a catalyst for economic development (Knight, 1995; Cooke \& Morgan, 1998). A basic idea here is that the competitiveness of a region is directly influenced by its ability to rapidly generate, access, understand and transform relevant knowledge and information as well as transform knowledge into learning (Keane \& Allison, 1999). The concept of a learning economy recognises knowledge as the most fundamental resource in the C-society and learning therefore as the most fundamental process (Lundvall \& Johnson, 1994). Of particular importance in the degree of 'collective learning', which connotes a broad notion of the capacity of a particular regional 'innovative milieu' to generate or facilitate innovative behaviour by the firms, who are members of that milieu (Camagni, 1991).

Learning regions function as collectors and repositories of knowledge and ideas, and provide the underlying environment or knowledge infrastructure, which facilitates the flow of knowledge, ideas and learning (Florida, 1995). The knowledge infrastructure is critical for the transformation of knowledge into learning. The knowledge infrastructure consists of two major parts: (i) the physical transport and communication infrastructure, which connects nodes with each other and bind the nodes together as well as provides arenas for human interaction, (ii) knowledge networks with universities, research institutes and other centres of learning as their major nodes. The importance of the tangible infrastructure cannot be overstated in this connection, since it can be related to the performance and productivity of regional economies (Smith, 1997; Batten \& Karlsson, 1996).

The comparative advantages of learning regions are based upon the emergence of new ideas, knowledge creation, organisational learning, and continuous improvements. A substantial part of their production is knowledge-based with continuous creation, knowledge as the main source of value and a synthesis between innovation and production. Firm networks and supplier systems function as the main sources of innovation. The human infrastructure is based on knowledge workers, continuous improvements of human resources and continuous education and training. The transportation and communication infrastructure is globally oriented as well as providing a high intra-regional accessibility. These regions are well connected electronically both externally and internally. The industrial governance system is based upon network organisations with mutually dependent relationships and a flexible regulatory framework. 
Besides the agglomeration economies and economies of scope available in all large urban regions, learning regions also seems to be characterised by institutional thickness (Indergaard, 1997), i.e. a high level of interaction based on relationships of trust and reciprocity (Keeble \& Lawson, 1998) and a mutual awareness of a common purpose (Keane \& Allison, 1999).

Maillat \& Kebir (2001) take the discussion of learning regions a step further by highlightning the processes which turn a region into a learning region. They claim that one must give the learning concept dynamic substance. For them learning is a process of acquisition and transformation of knowledge, which allows for permanent adaptation in the face of the uncertainty of the environment. They characterise the learning region as a dynamic and evolving region. It is dynamic because each actor, be it an individual, a firm, a public organisation or a network, is in continuous interaction (directly or indirectly) with his environment. It is evolving because each actor in the region participates in sequences of ongoing experiments. The learning region is also characterised by three types of ongoing processes: (i) a process of territorial implementation of innovation, (ii) a process of territorialisation of actors, and (iii) complex learning processes. These processes do not only occur within the different regions actors interacting with each other - but also through relationships each region fosters with other regions - the actors in a region interacting with actors in other regions.

\subsection{Knowledge Interaction in Regional Innovation Systems}

The concepts of creative and learning regions are related closely to the concept of innovation system. One definition of an innovation system says that it consists of a set of actors that interact in the generation and diffusion of new and economically useful knowledge (Fisher \& Fröhlich, 2001, Eds.). It is however possible to make a more explicit characterisation of the innovation system approach. This approach emphasises (de la Mothe \& Paquet, 1998):

- that firms must be viewed as part of a network of public and private sector organisations, whose activities and interactions initiate, import, modify and diffuse new technologies, 
- the linkages (both formal and informal) between organisations,

- the flows of intellectual resources that exist between organisations, and

- learning as a key resource and key process.

It is in this connection possible to differentiate between incoming and outgoing "spillovers”, when exploring how firms' R\&D cooperation with external partners affects the appropriation of new knowledge (Cassiman \& Veulgelers, 2002).

The literature offers conceptualisations and studies of many different types of innovation systems:

1. National innovation systems (Lundvall, 1995; Nelson \& Rosenberg, 1993).

2. Regional innovation systems (Cooke, et al., 1997 \& 1998; Andersson \& Karlsson, 2004 \& 2006).

3. Sectoral innovation systems (Breschi \& Malerba, 1997).

4. Technological systems (Carlsson \& Stankiewicz, 1991).

5. Metropolitan innovation systems (Fischer, Revilla-Diez \& Snickars, 2001).

6. Spatial innovation systems (Malecki \& Oinas, 2002).

7. Scientific innovation system (Johansson \& Lööf, 2006).

8. Vertical innovation system (Cox, Mowatt \& Prevezer, 2003; Johansson \& Lööf, 2006).

9. Horizontal innovation system (Cox, Mowatt \& Prevezer, 2003; Johansson \& Lööf, 2006).

10. Global innovation systems (Spencer, 2003; Johansson, Lööf \& Rader Olsson, 2005).

Obviously, firms can be involved in and interacting with other economic agents within many different types of innovation systems. Here, we concentrate on the role of location of firms for their innovative activities, i.e. on knowledge interaction in regional innovation systems. A focus on regional innovation systems does not imply that interregional interaction is unimportant for innovation but that intra-regional interaction in many (most?) cases play a more important role for innovation since the frequency of face-to-face interaction tends to decrease with time distance due to the 
tyranny of distance. Many researchers have also acknowledged the role of regional economic milieu for the innovativeness of firms (Andersson \& Karlsson, 2006). Informal routines, norms and institutions that are specific to each region are argued to play an essential role in the innovative behaviour of firms and the form and intensity of collaboration between them.

The location of a firm should matter to the extent that the regional economic milieu and in particular the knowledge resources and knowledge flows are different in different regions. A firm's innovation activities and interaction in different innovation systems is affected by proximity externalities (Johansson \& Lööf, 2006). If the self-organised knowledge externalities are weak in a region this implies on the one hand that firms may try to avoid to settle in such a region, and on the other hand that firms with innovative ambitions already located in such a region have incentives to try to establish and organise innovation system interaction in a more explicit way, based on formal agreements and planning. There is today a substantial agreement among scholars that the proximity gained by locating in large urban regions creates an advantage for innovative activities within firms by facilitating information and knowledge flows (Artle, 1959; Vernon, 1962; Glaeser, 1999; Feldman \& Audretsch, 1999) - a so-called proximity-based communication externality (Fujita \& Thisse, 2002; Johansson \& Quigley, 2004).

Proximity externalities are mainly to be found within the borders of functional urban regions, as they define the geographical area within which frequent face-to-face interaction can take place (Johansson \& Lööf, 2006). Various definitions of functional urban regions have been provided, for example, by Cheshire and Gordon (1995 and 1998) for Europe, and by Johansson, Klaesson \& Olsson (2002) for Sweden. In the latter case, a functional urban region is identified as a set of municipalities (cities and towns) between which the labour market commuting is mutually intense. Within functional regions the average car travel time between different municipalities is between 20 and 50 minutes compared the car travel time between municipalities, which belongs to different functional regions in most cases extends far beyond one hour. Thus, it is natural to assume that proximity externalities occur mainly within functional regions (Karlsson \& Manduchi, 2001), which highlights the importance of regional innovation systems. A major element in the analysis of regional innovation 
systems is the assumption about distance-sensitive knowledge flows, implying that knowledge spillovers are bounded in space (Varga, 2002).

How and to what extent do the regional innovation systems in various functional regions differ in their capacity to foster innovation activities by firms? First, they can differ in the amount, variety, and richness of knowledge resources and possibilities for an innovative firm to interact with other economic actors that embody various 'pieces' of critical knowledge. Second, they can vary in terms of the intra-regional supply of knowledge-intensive labour, whose knowledge diffuses as they find new jobs at other firms over time. Third, functional regions vary in terms of their intra-regional accessibility to customers, suppliers, and competitors as well as to knowledge providers such as universities, R\&D laboratories, firms conducting $R \& D$, and consultancy firms (Henderson, 1974; Audretsch \& Feldman, 1996; Karlsson \& Johansson, 2006; Gråsjö, 2006).

The critical question is of course the volume, intensity, and type of knowledge interaction taking place in regional innovation systems. Karlsson \& Johansson (2006) presents a classification of knowledge flows to a firm (Table 1.). Knowledge flows can be transaction-based, transaction-related, or pure knowledge spillovers. In the literature there has been a much (too much?) focus on the pure knowledge spillovers. Initially much effort was put into studies of "paper trails” (Jaffe, Trajtenberg \& Henderson, 1993) but over time, the focus has shifted partly to the mobility of people (Zucker, Darby \& Armstrong, 1998). On the one hand, knowledge interaction in regional innovation systems depends on both the R\&D intensity of the firms and their products, and the human capital intensity of the labour force. On the other hand, the interaction depends also on how well integrated the firms are in terms of deliveries, and cooperation and the extent to which employees with embodied knowledge move between firms. Interaction, cooperation, and job mobility are all functions of intra-regional accessibility. On top of that, we have the general regional economic milieu and what it provides in terms of institutions of R\&D and higher education and how well the region is connected with customers, suppliers and knowledge providers in other regions. Taken together these considerations point in the direction that large urban regions with a high intra-regional accessibility generally offers the best conditions for efficient regional innovation systems. 
Table 1 Classification of knowledge flows to a firm

\begin{tabular}{|l|r|}
\hline $\begin{array}{l}\text { Major types of } \\
\text { knowledge flows }\end{array}$ & Examples of knowledge flows \\
\hline $\begin{array}{l}\text { Transaction-based } \\
\text { flows }\end{array}$ & $\begin{array}{l}\text { 1. } \begin{array}{l}\text { Flows from knowledge providers that sell knowledge } \\
\text { that is used as an input to a firm's R\&D activities. }\end{array} \\
\text { 2. Flows in the form of inventions (innovations) that are } \\
\text { sold to the firm (e.g. by licensing a patent) }\end{array}$ \\
3. Knowledge flows between firms that cooperate in R\&D \\
projects, where costs and benefits are regulated by ex- \\
plicit contracts.
\end{tabular}

Source: Karlsson \& Johansson (2006)

We also have to consider the evolution of regional innovation systems over time. Economic history provides numerous examples of regional innovation systems that have stagnated for various reasons. Obviously, regional innovation systems can develop along trajectories that are not sustainable in the long run. The long-term sustainability of regional innovation systems has not been a major issue in the literature and is certainly a field where more research is needed in the future.

\section{KNOWLEDGE, SPECIALISATION AND GROWTH}

\subsection{Knowledge Patterns in Large and Small Regions}

In the previous section, we recognise that self-reinforcing processes, in which regions endowed with highly educated labour attract firms with activities critically dependent upon good access to knowledge intensive labour. As more firms move into these re- 
gions the demand for amenities as well as for highly educated labour stimulates investments in amenities as well as the in-migration of highly educated labour. Thus, virtuous cycles might emerge stimulating agglomeration of knowledge and creative potential. (Glaeser \&Kohlhase (2004); Cheshire \& Magrini (2005).

The research in the period 1960-2000 has lead to conclusions that make a majority of scholars agree that the proximity afforded by locations in large urban regions creates an advantage for firms by facilitating information and knowledge flows, following arguments presented in Artle (1959), Vernon (1962), Henderson (1974), Glaeser (1999), and Feldman \& Audretsch (1999). This phenomenon may be classified as proximity-based communication externality (Fujita \& Thisse, 2002; Johansson \& Quigley, 2004).

In most developed countries, a dominating share of all production takes place in the large urban regions. Most of the international and interregional trade takes place between these regions. Even more importantly, they are nodes in the international networks for knowledge and information transfer as well as milieus for creativity and innovation. Moreover, those large urban regions are characterised by a diversified pattern of small-scale activities that relate to dynamic urbanisation economies in the sense of Jacobs (1984). One important reason behind this is that many new technologies developed in recent decades have such a high complexity that the knowledge involved in the creation of these technologies are distributed over many individuals and organisational units (Karlsson, Flensburg \& Hörte, 2004). Thus, only large urban regions offer a broad enough knowledge base for developing these new technologies.

The versatile large urban region offers great advantages when it comes to introducing new economic activities. However, the economic history of urban regions show that such a relative advantage is easily lost and this loss has often a connection with the development of long-term product cycles (Andersson, 1985 a).

Small and medium-sized regions distinguish themselves by having limited local demand. Therefore, the local supply of distance-sensitive products (services) is not just smaller, but in particular less diversified. The second discriminating feature is that their knowledge resources are smaller. Furthermore, the share of labour with a long 
education is considerably smaller. Thus, these regions typically specialise in production based on natural resources including tourist amenities. They can also have a base in local clusters that support production for export to markets in other regions. They are also candidates for relocation of decomposed subroutines as outlined in the following two subsections (Johansson \& Karlsson, 2001).

\subsection{Spatial Product Cycles}

The product cycle theory is an attempt to develop a dynamic explanation to the division of labour between regions and nations (Vernon, 1966). In close association with the suggestions in the previous subsection, the product cycle theory assumes that firms introduce novel products with a higher than average frequency in urban regions with rich knowledge endowments and a creativity-stimulating milieu. The theory suggests and empirical observations provide support to the idea that those regions are large in most cases.

The theory adds a new dimension by outlining a dynamic process that generates a spatial division of activities over time, such that there are incentives to locate production in both smaller and larger regions. The main vehicle for this result is the transformations of a product (or product variety) and the associated production routines as (i) the product gradually becomes more standardised and (ii) the production routines develop towards automation and well coordinated but decomposable subroutines.

There are three fundamental perspectives, from which we can depict and analyse a product cycle. These three approaches should not be confused, and to make our analysis transparent we make the following observations:

(1) In the first, product cycle perspective, a product cycle model describes how product varieties in a novel product group increase their joint market share, usually at the expense of other established product groups, for which the market share reduces. Identifying such product cycle trajectories, the analysis can focus on where output of different product groups originates and to which markets the sales are destined. 
(2) In the second, firm perspective, a product cycle refers to the temporal development of product varieties that a single firm supplies. The firm perspective is particular, since a firm can have several different locations. Equally important, the single firm can over time initiate new product cycles, which implies that the firm rejuvenates itself by phasing out “obsolete” product varieties, while introducing new varieties, the development of which form new product cycles. Such a firm may develop its new products in one type of region and produce products with a declining market trend in another type of region.

(3) The third, region perspective is that of a region. In this case, certain regions may host the supply of young product varieties, while other regions persistently offer locations for the supply of product varieties with stagnating or declining market shares.

Combining the first and the perspective, a product cycle model can be viewed as a dynamic complement to the classical theory of comparative advantages. It involves three types of industrial dynamics: (i) technological development, which introduces new products or changes the function or design of products, (ii) the introduction of new or improvements of old production processes, and (iii) changes of the market organisation via the creation of new market channels or changes in price and market policies.

The product cycle model provides a stylized framework for understanding the changes in the demand for different types of inputs over the life cycle of a product. The trajectory of a life cycle can be described with regard to an entire product group, comprising varieties that satisfy similar needs. A life cycle trajectory can also refer to the development of a firm's supply of one or several such varieties. When the focus is on a product group, we may recognise the juvenile stage of such a group when all its varieties are young, non-standardised objects, which are still in a process of design where the firms continue to experiment with the final attributes of each variety. In this early stage of development, the R\&D work can benefit from taking place in a creative milieu, where many types of knowledge resources are accessible to the design activities. The knowledge requirements are high (Vernon, 1966; Norton \& Rees, 1979; Malecki, 1981; Nijkamp, 1986) 
Given that the design and market penetration process is successful, the product group enters a phase when the output and sales of the new product varieties expand at a fast rate. In this phase, the pertinent firms have better opportunities to routinise the production, distribution and marketing activities, and this can further stimulate the expansion. The routinisation of firm operations is facilitated when the design of product varieties are standardised. As a consequence, the unit cost of each variety can be reduced, which will stimulate market penetration.

As indicated in Karlsson \& Larsson (1990) the trajectory described above implies a change in the competition strategy of a firm. The change is a shift from product-attribute competition to price competition. Product competition signifies a market behaviour where the individual supplier uses the combination of attributes of his product varieties as his most important measure to attract customers to himself and away from his competitors (Johansson, 1988). Attribute competition represents efforts to carry out price enhancing innovations, whereas price competition is based on a search for cost-saving innovations.

The spatial product cycle theory is based upon the assumption that every new product with a high probability will be launched in one or several advanced urban regions in the world after a phase of $R \& D$, testing and production in a small test scale. Such regions offer dynamic comparative advantages, i.e. they are characterised by high R\&D investments at the same time as they have good access to human capital. As a result, the production of the new products will normally take place in the region where they were developed, but the location may shift as standardisation and routinisation proceeds.

How does a product cycle unfold from the viewpoint of individual firms? For one thing, the individual firm may be innovative and develop new products over time, and thereby initiate new product cycles in a sequence. At the same time, the firm may relocate the production and supply of its products as they become more mature and less dependent on the creative milieu in which they emerged (Fischer \& Johansson, 1994). 
According to the basic assumptions of the product cycle theory, the production of new products can start to diffuse when they have become standardised. The degree of standardisation of a product group has a major influence on the market structure and innovation behaviour of firms. In one extreme case, the firm continues to supply mature products to mass markets, including staple goods with a high degree of standardisation. In the opposite extreme case a firm supplies non-standardised products, adjusts its product attributes to each specific customer group such that each delivery is unique in some sense. For firms of this type, the capability to adapt product characteristics to specific requirements becomes an essential aspect of their everyday production activity and make them dependent upon good accessibility to customers with a high enough willingness to pay for specific product characteristics. A firm strategy of this type must be based on monopolised knowledge sources and unique labour inputs. In these markets price is just one of several criteria, which influence the decision-making of a customer.

\subsection{Knowledge Intensity and Location Dynamics}

Product standardisation and process routinisation are key notions in the model of product cycle dynamics developed by Johansson \& Andersson (1998). Along a product cycle path the knowledge intensity is high when a product is non-standardised and the production process is non-routinised. Standardisation and routinisation implies reduced knowledge intensity. This indicates that in the spatial product cycle theory, the change processes are influenced by the characteristics of the entire labour force and knowledge accessibility in each region (Johansson \& Karlsson, 1986). Such overall regional attributes describe the economic environment of individual firms and indicate their possibilities of acquiring knowledge and information pertinent to their production segment. The regional attributes also show, which possibilities a firm has to adjust the competence profile of its staff. Regional labour market characteristics are closely related to the location of R\&D activities, cultural opportunities and regional infrastructure (Glaeser \& Kohlhase, 2004; Bolton, 2002).

In order to make the location dynamics in a product cycle model transparent, we shall investigate the cost of supplying a novel product from a firm located in region $s$ - in 
the early phase of the cycle. The market demand in the early phase is assumed to stimulate the supply to reach the volume $x$. The production requires two types of resources, where the $b$-type refers to basic resources and the $g$-type to knowledge resources. The latter are present in the form of fixed resources, $F_{g}$, and variable inputs, $g x$, where $g$ is the use of variable knowledge resources per unit output. In a similar way we identify the fixed basic resources by $F_{b}$, and the variable basic inputs by $b x$, where $b$ is the use of basic inputs per unit output.

Given the specifications above, $G(x)=F_{g}+g x$ denotes the total amount of knowledge resources and $B(x)=F_{b}+b x$ denotes the total amount of basic resources associated with the output $x$. We now consider two regions $s$ and $k$, where $\rho_{s}$ and $\rho_{k}$ denote the region-specific prices of basic resources, while $\omega_{s}$ and $\omega_{k}$ denote the regionspecific prices of knowledge resources. We assume that (i) $\rho_{s}>\rho_{k}$ and (ii) $\omega_{s} \leq \omega_{k}$, which implies that basic resources have a lower price in region $k$.

In the early stage of the product cycle, region s has a location advantage when the following inequality applies:

$$
C_{s}(x)=\rho_{s} B(x)+\omega_{s} G(x)<C_{k}(x)=\rho_{k} B(x)+\omega_{k} G(x)
$$

As the product cycle develops the output (and sales volume) increases to $x^{*}$, the fixed resource requirements change to $F_{g}^{*}$ and $F_{b}{ }^{*}$, and the variable input coefficients change to $g^{*}$ and $b^{*}$. At this mature stage we have $G^{*}\left(x^{*}\right)=F_{g}^{*}+b^{*} x^{*}$ and $B^{*}\left(x^{*}\right)=F_{b}^{*}+b^{*} x$. According to product cycle assumptions the technology satisfies the following two conditions: (i) $F_{g} / F_{b}>F_{g}^{*} / F_{b}^{*}$ and (ii) $g / b>g^{*} / b^{*}$. Therefore, the location advantages may shift in this mature phase of technology development such that

$$
C_{s}^{*}\left(x^{*}\right)=\rho_{s} B^{*}\left(x^{*}\right)+\omega_{s} G^{*}\left(x^{*}\right)>C_{k}^{*}(x)=\rho_{k} B^{*}\left(x^{*}\right)+\omega_{k} G^{*}\left(x^{*}\right)
$$


In the mature phase of development, knowledge resources play a less important role than in earlier phases. As the product cycle develops, the technology will change and this can imply that both $B\left(x_{t}\right) / x_{t}$ and $G\left(x_{t}\right) x_{t}$ fall as time, $t$, increases. However, if $G\left(x_{t}\right) x_{t}$ falls more then $B\left(x_{t}\right) / x_{t}$, then a shift in location advantage may occur such that

$$
\left(\rho_{s}-\rho_{k}\right) B^{*}\left(x^{*}\right)+\left(\omega_{s}-\omega_{k}\right) G^{*}\left(x^{*}\right)>0
$$

Figure 5.1 describes the development of knowledge and basic inputs over time, and the diagram emphasises that the regional price of knowledge resources plays a dominating role in the initial stages of a product cycle, while becoming gradually less important as the technology develops.

Students of product cycles have often argued that in mature stages firms start to employ large-scale routines, implying that $F_{b}$ increases with maturity (Utterback \& Abernathy, 1975; Andersson \& Johansson, 1984a; Klepper 1996). However, a more relevant hypothesis is that the individual firm decomposes its routines in mature phases, giving the firm opportunities to outsource several of the decomposed routines into a supply chain network. First, each such outsourced and routinised activity can be located in a region with low costs of basic resources. Second, the size of such units may not be extremely large. At the same time, the entire supply chain can still represent a large-scale operation.

Consider now an outsourced production unit executing a sub-routine operation in a low cost location. It seems likely that such a production unit will give priority to process innovations in line with model predictions in Klepper (1996) or Andersson \& Johansson (1984a \& 1984b). At the same time, the "headquarter firm” may focus on development of new product varieties, and hence focus on product innovations. In such a scenario, a multi-unit firm would have firm units in both knowledge-intensive regions and in regions with a comparative advantage in routine-like activities. 


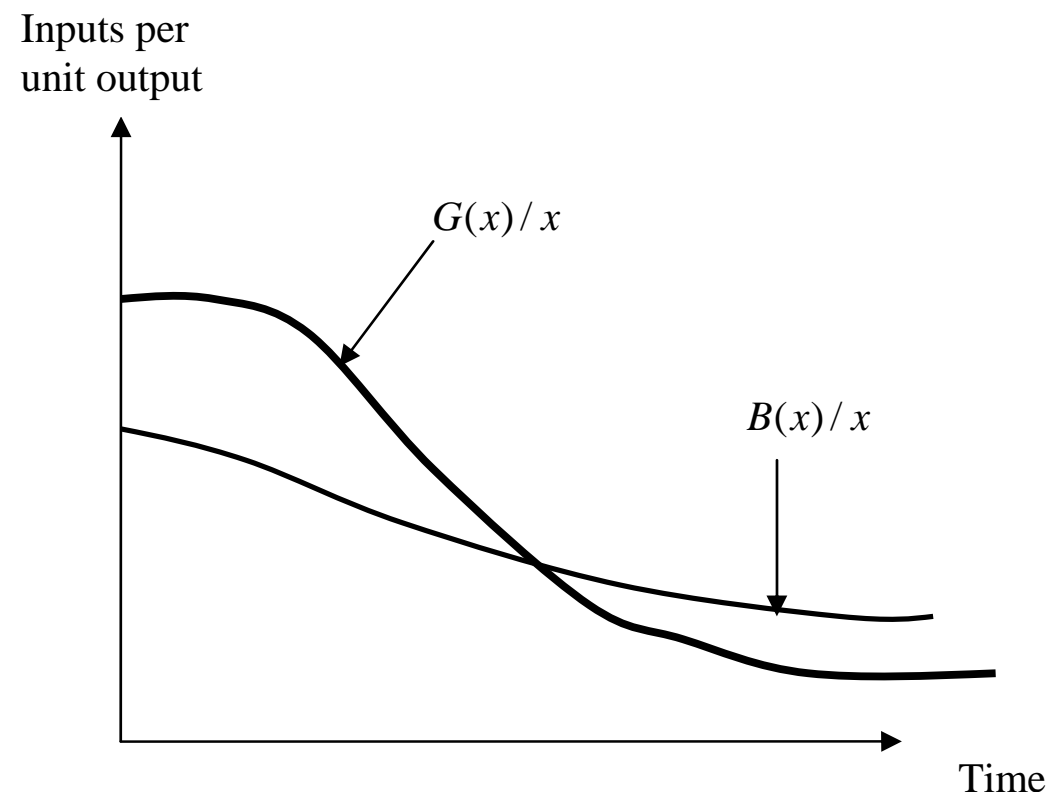

Figure 5.1: Knowledge resources per unit output fall faster than basic resources per unit output

Innovation studies that examine the role of corporate structure seem to provide support to the conclusion that multinational firms remain R\&D intensive in their respective home country, where they continue to generate product innovations, while at the same time locating production units in less knowledge-intensive regions around the world (Freeman, 1992; Crisculo, Narula \& Verspagen, 2005; Ebersberger \& Lööf, 2005). Such innovation persistent enterprises continue to keep a large share of their innovation activities in knowledge-intensive regions in their home country. Such behaviour also helps to stimulate these regions to remain rich in knowledge resources and to maintain their creative milieus.

Figure 5.2 illustrates the outcome of innovation processes that are dominated by the decisions by multinational firms. The figure is based on a classification of products (product groups) with regard to their market share in a global context. When the market share is large and growing the prediction is that a large share of the production is located in knowledge-intensive urban regions. As the growth of market share ceases, an increasing part of the production takes place in other regions, due to outsourced activities and imitation of followers in these regions. Observe that the figure does not inform about the market share of firms in each individual region. 
According to the figure, certain urban regions will remain as milieus for recurrent innovations, whereas other locations may host relocated, decomposed production activities. The arrows in the figure depict how the spatial pattern changes as technology develops from early to mature and finally declining stages. Indirectly, the figure also presents a pattern of specialisation, where certain regions specialise in "young” and others in "old" product cycles.

\begin{tabular}{|l|l|l|}
\hline $\begin{array}{l}\text { Novel } \\
\text { products }\end{array}$ & $\begin{array}{l}\text { Growing market } \\
\text { share of the } \\
\text { product }\end{array}$ & $\begin{array}{l}\text { Falling market } \\
\text { share of the } \\
\text { product }\end{array}$ \\
\hline $\begin{array}{l}\text { Large } \\
\text { market } \\
\text { share }\end{array}$ & $\begin{array}{l}\text { (I) Regions with } \\
\text { high knowledge } \\
\text { intensity }\end{array}$ & $\begin{array}{l}\text { (II) Regions with } \\
\text { medium knowledge } \\
\text { intensity }\end{array}$ \\
\hline $\begin{array}{l}\text { Low } \\
\text { market } \\
\text { share }\end{array}$ & $\begin{array}{l}\text { (III) Regions with } \\
\text { low knowledge } \\
\text { intensity }\end{array}$ \\
\hline
\end{tabular}

Figure 5.2: Global market share of a product and relocation dynamics

\section{CONCLUSIONS FOR REGIONAL DEVELOPMENT POLICIES}

\subsection{Knowledge as a Supply-Based Regional Advantage}

A region's location advantages can be viewed from two perspectives: (i) supply-based and (ii) demand-based advantages. The regional supply of resources of importance to firms (and potential firms) in a region can be depicted by the accessibility that individual firms have to these resources:

- Accessibility to labour categories with different human capital profiles 
- Accessibility to input suppliers, including service and knowledge providers

- Accessibility to venture capital

- Accessibility to $R \& D$ resources in other firms, research laboratories and universities

- Capacity and quality of infrastructure

- Institutions and entrepreneurship traditions

Accessibility to knowledge-intensive labour obtains for firms in regions, which are capable of attracting households that supply this labour. Hence, the regional consumption and cultural milieu as well as regional amenities of other kinds are crucial features. Many attractive attributes of a region are related to the size of the local market. Thus, demand-based advantages relate to urbanisation economies, providing household with diversified consumption opportunities and firms with diversified demand.

\subsection{Regional Policy for Knowledge-Based Development}

Location advantages evolve slowly in path-dependent processes. This is especially true for knowledge-based advantages. To be successful, regional policy therefore has to focus on structural adjustments of tangible and non-tangible infrastructure. Universities and university colleges are agents of human capital formation and may support enhancement of local knowledge assets, while various non-profit organisations and similar institutions may catalyse the formation of social capital.

In view of the arguments put forward in this chapter, it is possible to identify four areas for regional policies that relate to a region's knowledge resources:

- Knowledge policies, focusing on education and training of the labour force, development of innovation systems that support R\&D, patenting, product and commercial innovations, and improving the capacity to absorb external knowledge diffusion processes.

- Household milieu policies, influencing life conditions by forming human and social capital, and enriching households’ opportunities with regard to recrea- 
tion, job accessibility and natural environment attributes. Knowledge workers are far more demanding in these respects than the labour force on average.

- Facility policies, comprising built infrastructure for urban life, transport, internet and telecommunications, property development, urban management including transport demand, and land value mechanisms.

- Firm milieu policies, stimulating technology diffusion, facilitating supply of venture capital, supporting firm start-ups and direct investments by external firms, orchestrating cluster formation, and improving conditions for labour market adjustments. 


\section{References}

Andersson, M. \& O. Ejermo (2004), Sectoral Knowledge Production in Swedish Regions 1993-1999, in Karlsson, C., P. Flensburg \& S.-A. Hörte (2004) (Eds.), Knowledge Spillovers and Knowledge Management, Edward Elgar, Cheltenham, 143-170.

Andersson M. \& O. Ejermo (2005), How does Accessibility to Knowledge Sources Affect the Innovativeness of Corporations? - Evidence from Sweden, Annals of Regional Science, 39:741-765.

Andersson, M. \& C. Karlsson (2004), The Role of Accessibility for the Performance of Regional Innovation Systems, in Karlsson, C., P. Flensburg \& S.-Å. Hörte (2004) (Eds.), Knowledge Spillovers and Knowledge Management, Edward Elgar, Cheltenham, 283-310.

Andersson, M. \& C. Karlsson (2006), Regional Innovation Systems in Small and Medium-Sized Regions, in Johansson, B., C. Karlsson \& R. Stough (2006) (Eds.), The Emerging Digital Economy. Entrepreneurship, Clusters and Policy, Springer, Berlin, 55-81.

Andersson Å E (1981), Structural Change and Technological Development, Regional Science and Urban Economics 11, 351-361.

Andersson, Å.E. (1985 a), Kreativitet - Storstadens framtid, Prisma, Stockholm.

Andersson, Å.E. (1985 b), Creativity and Economic Dynamic Modelling, in Batten, D., J. Casti \& B. Johansson (1985) (Eds.), Economic Evolution and Structural Adjustment, Springer, Berlin, 27-45.

Andersson, Å.E. (1985 c), Creativity and Regional Development, Papers of the Regional Science Association 56, 5-20.

Andersson Å.E. (1986), The Four Logistical Revolutions, Papers of the Regional Science Association 59, 1-12.

Andersson, Å.E. (1988), Universitet - Regioners Framtid, Regionplanekontoret, Stockholm (in co-operation with B. Hårsman \& J. Linzie).

Andersson, Å.E. \& B. Johansson (1984 a), Industrial Dynamics, Product Cycles, and Employment Structures, WP-84-9, IIASA, Laxenburg.

Andersson, Å.E. \& B. Johansson (1984 b), Knowledge Intensity and Product Cycles in Metropolitan Regions, WP-84-13, IIASA, Laxenburg.

Andersson, Å.E. \& J. Mantsinen (1980), Mobility of Resources: Accessibility of Knowledge and Economic Growth, Behavioural Science 25, 353-366.

Andersson, Å.E. \& U. Strömqvist (1989), K-samhällets framtid, Prisma, Stockholm.

Antonelli, C., R. Marchionatti \& S. Usai (2003), Productivity and External Knowledge: The Italian Case, Rivista Internazionale di Scienze Economiche e Commerciali 50, 69-90

Arrow K.J. (1962), Economic Welfare and the Allocation of Resources for Invention, in R Nelson (ed), The Rate and Direction of Inventive Activity, NBER, Princeton University Press.

Artle, R. (1959), The Structure of the Stockholm Economy - Toward a Framework for Projecting Metropolitan Community Development, Business Research Institute, Stockholm School of Economics, Stockholm.

Audretsch, D.B. \& M.P. Feldman (1996), R\&D Spillovers and the Geography of Innovation and Production, American Economic Review 86, 630-640. 
Aydalot P. \& D. Keeble (1988), High-technology Industry and Innovation Environments: The European Experience, Routledge and Kegan Paul, London.

Barro R.J. \& X. Sala-i-Martin (1995), Economic Growth, McGraw-Hill, New York.

Batten , D.F. \& C. Karlsson (1996) (Eds.), Infrastructure and the Complexity of Economic Development, Springer, Berlin.

Beckmann M.J. (1994), On Knowledge Networks in Science: Collaboration among Equals, Annals of Regional Science 28, 233-242.

Beckmann M.J. (2000), Interurban Knowledge Networks, in Batten, D. (ed), Learning, Innovation and Urban Evolution, Kluwer Academic, London, pp 127-135.

Bolton R.E. (2002), Place Surplus, Exit, Voice and Loyalty, in B. Johansson, C. Karlsson and R.R, Stough (eds), Regional Policies and Comparative Advantage, Edward Elgar, Cheltenham.

Breschi, S. \& F. Malerba (1997), Sectoral Innovation Systems: Technological Regimes, Schumpeterian Dynamics and Spatial Boundaries, in Edquist, C. (1997) (Ed.), Systems of Innovation: Technologies, Institutions and Organisations, Pinter, London, 261-287.

Camagni, R. (1991), Local 'Milieu', Uncertainty and Innovation Networks: Towards a New Dynamic Theory of Economic Space, in Camagni, R. (1991) (Ed.), Innovation Networks: Spatial Perspectives, Belhaven, London, 121-142.

Carlsson, B. \& R. Stankiewicz (1991), On the Nature, Function and Composition of Technological Systems, Journal of Evolutionary Economics 1, 93-118.

Cassiman, B. \& R. Veugelers (2002), R\&D Cooperation and Spillovers: Some Empirical Evidence from Belgium, American Economic Review 92, 1169-1184.

Castells, M. (1989), The Informational City, Blackwell, Oxford.

Chambers R.G. (1988), Applied Production Analysis - A Dual Approach, Cambridge University Press, Cambridge.

Cheshire, P. \& I. Gordon (1995) (Eds.), Territorial Competition in an Integrating Europe, Avebury, Aldershot.

Cheshire P. \& I. Gordon (1998), Territorial Competition: Some Lessons for Policy, Annals of regional Science 32, 321-346.

Cheshire P. \& S. Magrini (2002), Counteracting the Counterfactual: New Evidence on the Impact of Local Policy from the Residuals, in B. Johansson, C. Karlsson and R.R, Stough (eds), Regional Policies and Comparative Advantage, Edward Elgar, Cheltenham, 209-238.

Cheshire, P. \& S. Magrini (2005), Regional Demographic or Economic Dynamism? Different Causes, Different Consequences. Paper presented at the international workshop “Innovation, Dynamic Regions and Regional Dynamics”, June 16-18, 2005, Jönköping, Sweden

Cooke, P. \& K. Morgan (1998), The Associational Economy, Oxford University Press, Oxford.

Cooke, P., M.J. Uranga \& G. Etxebarria (1997), Regional Innovation Systems: Institutional and Organisational Dimensions, Research Policy 26, 475-491.

Cooke, P., M.J. Uranga \& G. Etxebarria (1998), Regional Systems of Innovation: An Evolutionary Perspective, Environment and Planning A 30, 1563-1584.

Cornes R. \& T. Sandler (1986), The Theory of Externalities, Public Goods and Club Goods, Cambridge University Press, Cambridge.

Criscuolo P., R. Narula \& B. Verspagen (2005), The Role of Home and Host Country Innovation Systems in R\&D Internationalisation: A Patent Citation Analysis, Economics of Innovation and New Technology, 14:417-433. 
Cox, H., S. Mowatt \& M. Preverzer (2003), New Product Development and Product Supply within a Network Setting: The Chilled Ready-Meal Industry in the UK, Industry and Innovation 10, 197-217.

de la Mothe, J. \& G. Paquet (1998), National Innovation Systems, Real Economies and Instituted Processes, Small Business Economics 11, 101-111.

Denison E.F. (1962), The Sources of Economic Growth in the United States and the Alternatives before Us, Committee for Economic Development, New York.

Denison E.F. (1967), Why Growth Rates Differ: Post-War Experience in Nine Western Countries, Brookings Institution, Washington DC.

Dixit, A. \& J. Stiglitz (1977), Monopolistic Competition and Optimum Product Diversity, American Economic Review 67, 297-308.

Dosi G. et.al., (1988), (Eds.) Technical Change and Economic Theory, Pinter Publishers, London.

Dunning H.H. \& R. Narula (1995), The R\&D Activties of Foreign Firms in the United States, International Studies of Management \& Organization 25, 39-73

Ebersberger, B. \& H. Lööf (2005), Innovation Behaviour and Productivity Performance in the Nordic Region - Does Foreign Ownership Matter?, CESIS Working Paper No. 27, Centre for Science and Innovation Studies, The Royal Institute of Technology, Stockholm.

Feldman M.P. \& D.B. Audretsch (1999), Innovation in Cities: Scienced-Based Diversity, Specilisation and Localized Competition, European Economic Review 43, 409-429.

Fischer, M.M. \& J. Fröhlich (2001) (Eds.), Knowledge, Complexity and Innovation Systems, Springer, Berlin.

Fischer, M.M. \& B. Johansson (1994), Networks for Process Innovation by Firms: Conjectures from Observations in Three Countries, in Johansson, B., C. Karlsson \& L. Westin (1994) (Eds.), Patterns of a Network Economy, Springer, Berlin, 261-274.

Fischer, M.M., J. Revilla-Diez \& F. Snickars (2001), Metropolitan Innovation Systems. Theory and Evidence from Three Metropolitan Regions in Europé, Springer, Berlin.

Florida, R. (1995), Toward the Learning Region, Futures 27, 527-536.

Florida, R. (2002), The Rise of the Creative Class, Basic Books, New York.

Florida, R. (2005a), The Flight of the Creative Class. The New Global Competition for Talent, Harper Business, New York.

Florida, R. (2005b), Cities and the Creative Class, Routledge, New York.

Freeman C. (1992), Formal Scinetific and Technical Institutions in the National System of Innovation, in B. Lundvall (1992) (ed), National Systems of Innovation: Towards a Theory of Innovation and Interactive Learning, Pinter Publishers, London.

Fujita, M. \& J.F. Thisse (2002), Economics of Agglomeration - Cities, Industrial Location and Regional Growth, Cambridge University Press, Cambridge.

Glaeser, E. (1999), Learning in Cities, Journal of Urban Economics 100, 254-277.

Glaeser E.L. and J.E. Kohlhase (2004), Papers in Regional Science 83, 197-228.

Griliches Z. (1995), R\&D and Productivity: Economic Results and Measurement Issues, in P. Stoneman (1995) (ed), Handbook of the Economics of Innovation and Technological Change, Blackwell, Oxford, 52-89.

Grossman, G.M. \& Helpman, E. (1991), Quality Ladders and Product Cycles, Quartely Journal of Economics 106, 557-586. 
Gråsjö, U. (2006), Spatial Spillovers of Knowledge Production - An Accessibility Approach, JIBS Dissertation Series No 034, Jönköping International Business School.

Hall, P. (1990), High-Technology Industry and the European Scene, in SOU 1990:33, Urban Challenges, Statens offentliga utredningar, Stockholm, 117-133.

Hall P. \& P.Preston (1988), The Carrier Wave: New Information Technology and the Geography of Innovation, 1846-2003, Unwin Hyman, London.

Henderson, J.V. (1974), The Size and Type of Cities, American Economic Review 89, 640-656.

Indergaard, M. (1997), Community-base Restructuring?: Institution Building in the Industrial Midwest, Urban Affairs Review 32, 662-682.

Jaffe, A.B., M. Trajtenberg \& R. Henderson (1993), Geographical Localisation of Knowledge Spillovers as Evidenced by Patent Citations, Quarterly Journal of Economics 108, 577-598.

Jacobs, J. (1984), Cities and the Wealth of Nations, Random House, New York.

Johansson, B. (1988), Innovation Processes in the Swedish Network of Export and Import Nodes, Working Paper from CERUM, Umeå University, Umeå.

Johansson, B. \&Å.E. Andersson (1998), A Schloss Laxenburg Model of Product Cycle Dynamics, in Beckmann, M.J., et al. (1998) (Eds.), Knowledge and Networks in a Dynamic Economy, Springer, Berlin, 181-219.

Johansson B. \& C. Karlsson (1992), Transportation Infrastructure of the Mälar Region, Regional Studies 28, 169-185.

Johansson, B. \& C. Karlsson (1986), Industrial Application of Information Technology: Speed of Introduction and Labour Force Competence, in Nijkamp, P. (1986) (Ed.), Technological Change, Employment and Spatial Dynamics, Springer, Berlin, 401-428.

Johansson, B. \& C. Karlsson (2001), Geographic Transaction Costs and Specialisation Opportunities of Small and Medium-sized Regions: Scale Economies and Market Extension, in Johansson, B., C. Karlsson \& R.R. Stough (2001) (Eds.), Theories of Endogenous Regional Growth - Lessons for Regional Policies, 150180.

Johansson, B., J. Klaesson \& M. Olsson (2002), Time Distances and Labour Market Integration, Papers in Regional Science 81, 305-327.

Johansson, B. \& H. Lööf (2006), Innovation Activities Explained by Firm Attributes and Location, CESIS Working Paper No. 63, Centre of Excellence for Science and Innovation Studies, The Royal Institute of Technology, Stockholm.

Johansson, B., H. Lööf \& A. Rader Olsson (2005), Firm Location, Corporate Structure, R\&D Investment, Innovation and Productivity, CESIS Working Paper No. 31, Centre of Excellence for Science and Innovation Studies, The Royal Institute of Technology, Stockholm.

Johansson, B. \& J. Quigley (2004), Agglomeration and Networks in Spatial Economies, Papers in Regional Science 83, 165-176.

Kaldor N. (1963),, Capital Accumulation and Economic Growth, in Lutz, F.A. \& D.C. Hague (1963) (Eds), The theory of capital: Proceedings of a Conference Held by the International Economic Association, ,Macmillan, London, 177-222.

Karlsson, C. \& M. Andersson (2006), The Location of Industry R\&D and the Location of University R\&D - How Are They Related?, in Karlsson, C., et al., (2006) (Eds.), Innovation, Dynamic Regions and Regional Dynamics, Springer, Berlin, (Forthcoming). 
Karlsson, C., P. Flensburg \& S.-Å. Hörte (2004), Introduction: Knowledge Spillovers and Knowledge Management, in Karlsson, C., P. Flensburg \& S.-Å. Hörte (2004) (Eds.), Knowledge Spillovers and Knowledge Management, Edward Elgar, Cheltenham, 3-31.

Karlsson C. \& B. Johansson (2006), Dynamics and Entrepreneurship in a KnowledgeBased Economy, in C. Karlsson, B. Johansson \& R.R. Stough (eds), Entrepreneurship and Dynamics in the Knowledge Economy, Edward Elgar, Routledge, New York, 12-46.

Karlsson, C. \& J. Larsson (1990), Product and Price Competition in a Regional Context, Papers of The Regional Science Association 69, 83-99.

Karlsson, C. \& A. Manduchi (2001), Knowledge Spillovers in a Spatial Context - A Critical Review and Assessment, in Fischer, M.M. \& J. Fröhlich (2001) (Eds.), Knowledge, Complexity and Innovation Systems, Springer, Berlin, 101-123.

Keane, J. \& J. Allison (1999), The Interaction of the Learning Region and local and Regional Economic Development: Analysing the Role of Higher Education, Regional Studies 33, 896-902.

Keeble, D. \& C. Lawson (1998) (Eds.), Collective Learning Processes and Knowledge Development in the Evolution of Regional Clusters of High Technology SMEs in Europe, ESRC Centre for Business Research, University of Cambridge.

Klepper, S. (1996), Exit, Entry, Growth and Innovation over the Product Life Cycle, American Economic Review 86, 562-583.

Knight, R.V. (1995), Knowledge Based Development: Policy and Planning Implications for Cities, Urban Studies 32, 225-260.

Kobayashi, K. (1995), Knowledge Networks and Market Structure: An Analytical Perspective, in Batten, D.F., J. Casti \& R. Thord (1995) (Eds.), Networks in Action. Communication, Economics and Human Knowledge, Springer, Berlin, 127158.

Kobayashi, K. \& Å.E. Andersson (1994), A Dynamic Input-Output Model with Endogenous Technical Change, in Johansson, B., C. Karlsson \& L. Westin (1994) (Eds.), Patterns of a Network Economy, Springer, Berlin, 243-259.

Krugman, P. (1991), Geography and Trade, Leuven University Press, Leuven.

Kummerle, W. (1999), Foreign Direct Investment in Industrial Research in the Pharmaceutical and Electronics Industries - Results from a Survey of Multinational Firms, Research Policy 28, 179-193.

Lucas, R.E. (1988), On the Mechanics of Economic Development, Journal of Monetary Economics 22, 3-42.

Lundvall, B-Å. (1995), Introduction, in Lundvall, B-Å. (1995) (Ed.), Natioanl Systems of Innovation - Towards a theory of Innovation and Interactive Learning, Biddles, London, 1-19.

Lundvall, B.-Å. \& B. Johnson (1994), The Learning Economy, Journal of Industrial Studies 1, 23-42.

Maillat, D. \& L. Kebir (2001), The Learning Region and Territorial Production Systems, in Johansson, B., C. Karlsson \& R.R. Stough (2001) (Eds.), Theories of Endogenous Regional Growth. Lessons for Regional Policies, Springer, Berlin, 255-277.

Malecki E.J. (1981), Product Cycles and Regional Economic Change, Technological Forecasting and Social Change 19, 291-306.

Malecki, E. \& P. Oinas (2002), The Evolution of Technologies in Time and Space: From National and Regional to Spatial Innovation Systems, International Regional Science Review 25, 102-131. 
Morgan, K. (1997), The Learning Region: Institutions, Innovation and Regional Renewal, Regional Studies 31, 491-503.

Narula, R. (2002), Innovation Systems and 'Inertia' in R\&D Location: Norwegian Firms and the Role of Systemic Lock-in, Research Policy 31, 795-816.

Nelson, R.R. (1997), How New is the New Growth Theory?, Challenge 40, 29-58.

Nelson, R.R. \& N. Rosenberg (1993), Technical Innovation and National Systems, in Nelson, R.R. (1993) (Ed.), National Innovation Systems - A Comparative Analysis, Oxford University Press, New York, 3-21.

Nelson, R.R. \& S.G. Winter (1982), An Evolutionary Theory of Economic Change, Harvard University Press, Cambridge, MA.

Nijkamp P., ed. (1986), Technological Change, Employment and Spatial Dynamics, Lecture Notes in Economics and Mathematical Systems, vol. 270, SpringerVerlag, Berlin.

Nijkamp, P. (2003), Entrepreneurship in a Modern Knowledge Economy, Regional Studies 37, 395-405.

Norton, R. \& J. Rees (1979), The product Life Cycle and the Decentralisation of American Manufacturing, Regional Studies 13, 48-90.

Noyelle, T.J. \& T.M. Stanbeck (1984), The Economic Transformation of American Cities, Rowman and Allanheld, Totowa.

Patel, P. \& K. Pavitt (1991), Large Firms in the Production of the World's Technology: An Important Case of 'Non-Globalisation', Journal of International Business Studies 22, 1-21.

Pfaffermayr M. \& C. Bellak (2002), Why Foreign-Owned Firms are Different: A Conceptual Framework and Empirical Evidence from Austria, in R. Jungnickel (2002) (ed), Foreign-Owned Firms: Are They Different?, Palgrave McMillan, London, 13-57.

Polanyi, M. (1966), The Tacit Dimension, Routledge \& Kegan Paul, Ltd, London.

Romer, P. (1986), Increasing Returns to Scale and Long-Run Growth, Journal of Political Economy 94, 1002-1037.

Romer, P. (1990), Endogenous Technological Change, Journal of Political Economy 98, 71-102.

Romer, P. (1994), The Origins of Endogenous Growth, Journal of Economic Perspectives $8,3-32$.

Schumpeter, J.A. (1934), The Theory of Economic Development, The MIT Press, Cambridge, MA.

Smith, K. (1997), Economic Infrastructure and Innovation Systems, in Edquist, C. (1997) (Ed.), Systems of Innovation: Technologies, Institutions and Organisations, Frances Pinter, London, 86-106.

Solow, R.M. (1994), Perspectives of Growth Theory, Journal of Economic Perspectives $8,45-54$.

Spencer, J.W. (2003), Firms' knowledge-sharing strategies in the global innovation system: empirical evidence from the flat panel display industry, Strategic Management Journal 24, 217-233.

Teece, D.J. (1981), The Market for Know-How and the Efficient International Transfer of Technology, Annals of the American Association of Political and Social Sciences 458, 54-67

Teece, D.J. (1998), Capturing Value from Knowledge Assets: The New Economy, Markets for Know-How, and Intangible Assets, California Management Review 40, 55-79. 
Utterback, J.M. \& W.J. Abernathy (1975), A Dynamic Model of Process and Product Innovation, OMEGA 3, 639-656.

Varga, A. (1997), University Research and Regional Innovation: A Spatial Econometric Analysis of Academic Technology Transfers, Kluwer Academic Publishers, Boston.

Varga A. (2002), Knowledge Transfers from Universities and the Regional Economy: A Review of the Literature, in Varga, A. \& L. Szerb (2002) (Eds.), Innovation, Entrepreneurship, Regions and Economic Development: International Experiences and Hungarian Challenges, University of Pécs, Pécs, 147-171.

Vernon, R. (1962), Metropolis 1985, Harvard University Press, Cambridge, MA.

Vernon, R. (1966), International Investment and International Trade in the Product Cycle, Quarterly Journal of Economics 80, 190-207.

Weibull J.W. (1976), An Axiomatic approach to the Measurement of Accessibility, Regional Science and Urban Economics 6, 357-379

von Hippel, E. (1994), Sticky Information and the Locus of Problem Solving: Implications for Innovation, Management Science 40, 429-439.

Zucker, L.G., M.R. Darby \& J. Armstrong (1998), Geographically Localised Knowledge: Spillovers or Markets?, Economic Inquiry 36, 65-86.

Zucker, L.G., M.R. Darby \& M.B. Brewer (1998), Intellectual Human Capital and the Birth of U.S. Biotechnology Enterprises, American Economic Review 88, 290306 